This is the accepted manuscript of the article, which has been published in Utopian Studies. 2019, 30(2), 193-213. https://dx.doi.org/10.5325/utopianstudies.30.2.0193

Maria Laakso, Toni Lahtinen, and Hanna Samola

\title{
Young Saviors and Agents of Change: Power, Environment, and Girlhood in Contemporary Finnish Young Adult Dystopias
}

Up until the end of the twentieth century, the dystopia was a practically nonexistent genre in Finnish literature. However, since the turn of the century, there has been a marked dystopian turn. In addition to the anxieties associated with the passing of the millennium, emerging global issues such as digital development, environmental problems, and terrorism have contributed to the ongoing popularity of dystopian fiction. ${ }^{1}$ At the same time, Finnish literature has been strongly influenced by the trends of international book markets. For example, the unprecedented popularity of dystopian young adult (YA) literature has inspired Finnish authors. In the past ten years, a number of writers have published post-apocalyptic visions of a world gone awry.

Contemporary Finnish dystopian fiction reveals the collective fears over the destruction of the Finnish welfare state. This grim and often violent fiction does not portray Finland as a Nordic utopia, but rather as a society in which the social welfare and the general well-being of citizens have collapsed as a result of, among other things, climate change, continuous wars, totalitarian regimes, consumer capitalism, and the repression of minorities. However, in the dystopian fiction aimed at adolescent audiences, optimism for a better future is also important. This hope is created through the possibility of change that only the next generations can bring. Therefore, one of the most important characteristic of the contemporary YA dystopias seems to be the strong active agency given to young characters. ${ }^{2}$

The trope of the child savior-in which a child or young person represents the hope of an otherwise doomed humankind—is common in Western YA dystopias. ${ }^{3}$ In contemporary YA dystopias, adolescence is almost an "antidote to corrupt adulthood."4 As Carrie Hintz and Elaine Ostry suggest, there is a long tradition of seeing childhood itself as utopian, a space and time apart from adult life and all its concerns. ${ }^{5}$ The emphasis on the innocence and purity of children is originally a Romantic idea, ${ }^{6}$ but this notion of utopian childhood is still present in contemporary YA dystopias, where the adolescent protagonist's idealistic and morally superior viewpoint can bring hope to a dark, dystopian future. ${ }^{7}$ 
In addition to the trope of the child savior, we will examine the independence and political and societal agency offered to young characters in Finnish YA dystopias published in the 2010s. We start by analyzing the societal roles, freedom, societal power, and agency of young characters in these works. We then concentrate on climate and ecological themes, which play a crucial role in the fictional worlds of contemporary Finnish YA dystopias. These ecodystopias often present young characters as members of generations with higher ecological awareness and therefore a capacity to change future ways of living. Finally, we discuss girlhood and references to fairy tales in the context of YA dystopias. In our material, intertextual references to fairy tales are commonly utilized when discussing the agency and power of young female characters in dystopian futures.

Although our article deals with a number of works of contemporary Finnish YA literature, we will specifically focus on the following dystopias: De hemlösas stad (2010 [The City of the Homeless], untranslated) by Annika Luther, Jäljellä (2012 [Without a Trace, untranslated) and Toisaalla (2012 [Elsewhere], untranslated) by Salla Simukka, Teemestarin kirja (2012, Memory of Water) by Emmi Itäranta, Nokkosvallankumous (2013 [Nettle Revolution], untranslated) by Siiri Enoranta, and Kevätuhrit (2016 [Spring Sacrifices], untranslated) by K. K. Alongi.

Power, freedom, and agency in Finnish YA dystopias

In Finnish YA dystopias, young protagonists often achieve societal power; they possess the ability to affect their society or community. This is noteworthy when compared to the actual world of the readers and authors. The role of young people in Finnish society is liminal when considered in the context of political structures and institutional practices. The same is true of the political positioning of young people in all Western cultures. In some contexts, young people are treated as competent, responsible, and reliable, whereas in other contexts, they are perceived as incompetent, irresponsible, and unreliable. ${ }^{8}$ This liminality or "in-betweenness" in relation to legal and political practices makes young people interesting political subjects. ${ }^{9}$

Contemporary Finnish dystopias examine the problematic societal agency of adolescents. This can be considered a relatively new phenomenon when compared to earlier traditions in Finnish YA literature. Previously, adolescence was often depicted as a time of turmoil or one of "storm 
and stress," with the conflict between the young protagonist and society often being caused by the protagonist's own adolescent turmoil. This is, of course, typical of the modern genre of adolescent literature, which often depicts the identity crises of protagonists. The themes of growing up and finding oneself are also typical of Finnish YA dystopias. However, a repressive society or a world ruined by the actions of earlier generations are now the root of the problems rather than identity crises. Therefore, the rebellion against society is justified and even admirable in the ethos of the texts. The rebellious adolescents bring the hope of a new and better future to the dystopian present and can even become saviors of the world.

In Siiri Enoranta's post-apocalyptic YA dystopia Nokkosvallankumous, the hope for a more equal and ecological society is placed on the shoulders of the young characters. The novel describes a future world in which nuclear accidents have polluted the soil and water, and people are starving. The corrupt Korotrato ministry pretends to follow the rules and principles of democracy, but in reality, it has allied itself with the unscrupulous "perinists," who wish to consolidate power and rule the world absolutely. In the novel, nation states have been dissolved and the world is dominated by a totalitarian regime. The merest hint of resistance is suppressed:

Most of the people were taken away three years ago, when things started to go visibly wrong. The destruction had been accumulating for decades, that much I learnt from my father. But three years ago, a quarter of our city’s residents vanished. Dangerous people were taken away. Those who saw, those who heard, those who raised their voices against Korotrato or its pets, the perinists. The only ones left were the children, old people, and the weak and beaten adults. ${ }^{10}$

The totalitarian regime, however, underestimates the power and courage of the young. One of the novel's two protagonists, a young boy called Dharan, leads a rebel group called "the nettles." The nettles consists of children and adolescents who live in an abandoned amusement park, a milieu that symbolizes a childhood ended too soon. Eventually, the oppression of the people accelerates, and hundreds of ordinary people come to join the rebel group, which is finally able to start a revolt against the oppressive regime. Dharan and the other members of the nettles become child saviors; they are the only ones able to challenge the adult-ruled world and change the course of the future. 
In Nokkosvallankumous, the opportunity for adolescents to become saviors or political agents in society is the result of old social hierarchies crumbling and decisively changing. In postapocalyptic YA dystopias, the social separation of powers is redefined, and young characters are offered a new range of functional opportunities or obligations. Whereas contemporary society seems not to offer teenagers much political agency or influence, dystopian fiction gives young people a role as political subjects. This is notable, especially when compared to classic dystopias like Orwell's 1984 (1949) or Huxley’s Brave New World (1932) that, by contrast, depict oppressive societies. Contemporary post-apocalyptic YA fiction might paradoxically offer a greater amount of freedom to individuals.

Many cultural models of child autonomy and child-governance can be found within the wider context of the tradition of children's and YA fiction. Kit Kelen and Björn Sundmark (2017, 2) list some relevant texts: The Secret Garden (1911), Peter Pan (1904), the Chronicles of Narnia (1950-1956), The Lord of the Flies (1954), The Silver Sword (1956), Seven Little Australians (1894), Tomorrow When the War Began (1993), Pippi Longstocking (1945), The Children of the New Forest (1847), and The Famous Five novels (1942-1963). As the list shows, the idea of child rule has been a popular one from a wide range of ideological perspectives and for readers of various ages. Nokkosvallankumous continues this tradition within the genre of YA dystopia. The post-apocalyptic world offers rebellious children and adolescents an opportunity to live by themselves according to their own rules, and even to affect the surrounding society. The child savior motif is therefore connected to the tradition of child rule stories.

In Nokkosvallankumous, the protagonist is a young orphan boy, Vayu, who has lived all his childhood in a poor village called Tuohikylä. His luck changes when he is accepted into the nettles:

I marveled at how clean and tidy everything was. And now, when I looked at Huhtikaunas [the amusement park] in the daylight, I noticed an orderliness I hadn't seen anywhere else for a long time. In Tuohikylä, everyone cared only for themselves and the result was that everybody lost. But the nettles were like the roots, stems, and leaves of one plant. ${ }^{11}$

The difference noted between the adult-ruled village and child-ruled amusement park is remarkable. The latter does not end up becoming a selfish chaos where each individual seeks 
his or her own ends, as one might imagine would happen if adolescents were to hold power. On the contrary, children's community takes care of the environment and is willing and able to work together for the greater good. The metaphor of the plant is apt given the group's name. The community is a living and breathing organism in which individuals help the shared plant body to flourish.

Some classical child rule stories present a carnivalesque child character that remains a child. Nevertheless, most child rule stories in Western children's fiction have a pedagogical message. When children gain power, they have to grow up and adopt adult-like qualities. A good example of this is the common plot of mastering another world and then returning to one's own with authority and new skills gained from experience. ${ }^{12}$ Characters inhabiting the dystopian world in Nokkosvallankumous cannot escape from their reality, but this story belongs to this latter type of work. In a dystopian world order, the children and adolescents can gain power, but at the same time they have to bear the responsibility that in the real world belongs to adults.

Childhood and adolescence, like all socially constructed categories, such as gender, class, and ethnicity, are complex and prone to constant negotiation and (re)definition. Generational discourses, like child rule stories, negotiate the power relationships between generations and the place of children within adult-ruled society. They legitimize the child-adult order while simultaneously erasing it. The methods of simultaneously liberating and controlling the child vary culturally and historically. ${ }^{13}$ In contemporary YA dystopias, one strong tendency is to highlight the failure of previous generations and express the hope for wiser and more capable adults in the future by offering stronger societal agency to adolescent characters.

Finnish post-apocalyptic YA fiction offers more power and freedom to young characters, because the institutions typically regulating adolescents' lives have transformed or disappeared. This is a concrete liberation from the power of adults. In the Nordic countries, like in all Western societies, the transition from childhood to adulthood happens within strictly regulated frameworks. Institutions in particular, such as the school and the family, try to teach children how to use the institutional power afforded to individuals. These institutions are also often depicted in YA literature to teach the readers about the power structures of modern society. In YA fiction, the school often serves as a metaphor for the many institutions that will influence adolescents throughout their (adult) lives. ${ }^{14}$ 
However, in post-apocalyptic YA dystopias, society may have fallen apart, and schools, the police force, the military, and other social institutions have vanished. K. A. Alongi's novel Kevätuhrit, a post-apocalyptic novel set in a near-future Helsinki, illustrates this well. The novel begins on one seemingly ordinary spring day, when almost everyone in Helsinki and apparently the whole world dies mysteriously. The only survivors are a few teenagers. The first survivors presented to the reader are two girls; they wander through a ghostly city filled with the bodies of their parents, neighbors, and teachers.

In Alongi's novel, all the institutions that previously regulated the lives of teenagers are swept away, and the young characters are free to do whatever they wish. However, the consequences of total freedom are mainly negative. As is also often the case with post-apocalypses written for adult audiences, the social contract unravels. Some of the surviving teenagers, whom the protagonists call “hooligans,” begin to commit random acts of violence.

This is not exceptional within the tradition of the child rule stories alluded to above, since some of them do not celebrate the societal power of children but rather depict the horrors of a childruled society. Lord of the Flies and Stephen King's novel Children of the Corn (1977) are wellknown examples of child-ruled communities descending into cruelty and violence. Interestingly, Lord of the Flies is also a classic prototype of dystopian fiction. Björn Sundmark stresses that one of the cornerstones of social order is the asymmetric power relationship between adults and children. ${ }^{15}$ We understand power and responsibility to be the prerogative of adults, and this means that dependence and obedience are considered attributes connected to children. When these fundamentals are altered or challenged, the social order itself is threatened. ${ }^{16}$

Accordingly, in the novel Kevätuhrit, the lack of adult authority leads to partial anarchy and turmoil among the survivors. The absolute freedom offered to (immature) kids turns the world into a horror show. On the other hand, the protagonists and some of the other adolescent survivors they meet maintain their ability to be helpful towards others and a willingness to follow some shared rules. Even though the collapse of adult society leads to anarchy, there still remain adolescents who are able to start from scratch and rebuild organized society. In Kevätuhrit, the child savior motif is not utilized as clearly as in Nokkosvallankumous, where the distinction between the generations is clearer and young characters hold the promise of a better future. 
Alongi's novel is also connected to the tradition of robinsonades, which form an important subgenre for child rule stories. Common motifs in robinsonades are familiar from the original novel: isolation, self-reliance, survival, and spiritual regeneration or inner growth. ${ }^{17}$ Many postapocalypses follow the generic models of robinsonades, since survival is always one of the main motifs of post-apocalyptic works. In Kevätuhrit, the young protagonists suddenly have to learn survival skills they previously never needed when living in modern society with all its comforts. In a changed world, these adolescents learn to evaluate the utility of articles and objects from a new perspective that is divorced from the capitalist system. This signals the novel's utopian hope for a better future, no matter how horrifying the present is for the survivors. The adolescent survivors are resilient enough to leave behind the world they used to know and head toward the future.

The change is not easy. On several occasions during the novel, the young survivors miss the old hierarchies that held organized society together. This certainly is the negative side of the freedom and active agency offered to the adolescent protagonists in post-apocalyptic YA dystopias. Nevertheless, freedom also brings with it positive effects; it allows the adolescents to grow up and find their own values and strength without the guidance of former generations. In this way, Nokkosvallankumous and Kevätuhrit share their utopian idea of the young characters being the ones with the capacity to build a better future. Even though previous generations have ruined the world and/or the conditions the children or adolescents live in are frightening, the hope remains.

Finnish eco-dystopias and climate fiction for young adults

The dystopian turn in Finnish literature at the beginning of the twenty-first century is acutely connected to the threats caused by the global environmental crisis. Consequently, YA literature has also become ever more populated with critical and provocative writing concerning ecocide. Climate fiction, a genre that aims to warn people of the effects of climate change, has become especially popular. In the 2010s, a distinct phenomenon of fictional narratives depicting floods, storms, drought, and warfare- the concrete consequences of climate change — can be detected in Finnish YA literature. These narratives challenge Finland's green, even ecotopian, national image that is an essential part of the modern Nordic welfare state. ${ }^{18}$ 
In the 1990s, before the popularity of global eco-dystopias, Finnish YA literature emphasized animal rights and environmental activism. A turning point in the history of the Finnish environmental movement was marked in 1995 when a series of ecotage attacks aimed at Finnish fur farms sparked a significant public debate. In the media, the environmental movement was seen as a threat to the Finnish social order and business, thus creating a need to address the motives of young activists through literature. However, the 2001 protests at the Genoa G8 summit and the 9/11 terrorist attacks had a calming effect on the European environmental movement and Finnish writers became more interested in questions of international terrorism than ecotage on Finnish fur farms. ${ }^{19}$ Whereas the protagonists of contemporary dystopias are often heroes, the preceding activist characters are mostly troubled or confused individuals.

Trends in the international literary market have also had an effect on Finnish ecologically oriented literature. Following Suzanne Collins’ The Hunger Games trilogy (2008-2010), a series of Finnish eco-dystopias were published, including Annika Luther's De hemlösas stad (2011), Anne Leinonen and Eija Lappalainen's Routasisarukset trilogy (Routasisarukset [Frost Sisters], 2011; Hiekkasotilaat [Sand Soldiers], 2012; Konejumalat [Machine Gods], 2013; all untranslated), Laura Lähteenmäki's North End trilogy (Niskaan putoava taivas [The Sky That Falls], 2012; Kaiken peittävä tulva [The Flood That Covers], 2013; Karrelle polttava helle (The Heat That Burns], 2014; all untranslated), Siiri Enoranta's Nokkosvallankumous, and Emmi Itäranta's Memory of Water (2012, Teemestarin kirja) and The City of Woven Streets (2015, Kudottujen kujien kaupunki). Following Collins's successful formula, most of these books feature a young girl or woman as the protagonist who must survive in a time following a major ecological disaster.

The ecological depictions in YA literature have consequently shifted towards speculative fiction and the post-apocalyptic world that portrays survival not only in extreme environmental conditions but also in a collapsed or radically changed social order. However, even global ecological threats have not managed to change the central motif of YA literature; even in environmental fiction, the protagonist's journey towards adulthood remains an important theme. Nevertheless, the new ecological problems offer an important ethical framework for these stories of personal growth; they reflect broader questions of national identity and changes in modern society through the young protagonist's identity and inner growth. ${ }^{20}$ Accordingly, 
the young and maturing protagonist as environmental savior has become a common figure in contemporary YA dystopia.

From the perspective of the Finnish welfare state, the most interesting eco-dystopia is Annika Luther's De hemlösas stad, a book that connects climate change with the topical question of refugees. The story is set in 2050, a time when, according to climatologists, there will be hundreds of millions of climate migrants. In 2035, tsunamis altered the continental shorelines radically. Helsinki was submerged, and Finland's capital is now the city of Jyväskylä in Central Finland. An Official Migrant Zone begins at the city’s southern border; it is populated by Dutch, Danish, Russian, Spanish, and Irish farmers. South of the Migrant Zone, there is a coastal region called the Risk District that is inhabited by millions of Asian climate refugees. The flooded Helsinki has also transformed into something more foreign, reflected in its new name, "Halsingih.”

In De hemlösas stad, a teenage girl’s flight from Jyväskylä to Helsinki details a confrontation with multiculturalism and the otherness of one’s own society. In works of YA literature, the journey of the protagonist often exposes the hierarchical power dynamics that are connected to the inequality between the rich and poor, men and women, and adults and children. ${ }^{21}$ Luther's writing shows that when the surface area of the continents shrinks, a flood of refugees will flow towards the welfare states of northern Europe and global inequality will grow. The journey also exposes the hierarchies in present-day society, as the story is connected to an ongoing debate about the EU's politics on immigration.

The spotlights of the city watch colored the southern sky with sickening shades of orange and grey. There, on the other side of those spotlights, began the Official Migrant Zone, which the EU had forced the Finns to turn into a settlement for those European farmers whose homelands had become either too wet or too dry to farm. In Southern Finland, potatoes grew better than ever and the long, gentle autumns had turned corn cropping into a prolific business. Without Sweden and Finland, the entire EU would have starved a long time ago, but in Jyväskylä people agreed that the EU had interfered unforgivably with Finland's domestic affairs when they forced the Finns to receive a pack of foreigners. ${ }^{22}$ 
The way the story depicts a safe haven for the privileged, a closed and guarded community, is compatible with classic dystopias that feature a protagonist who feels like an outsider and questions the values of the utopian society. ${ }^{23}$ The Jyväskylä of the future resembles an Orwellian dystopia in the way the city practices extreme control over its citizens. A Big Brother type of system - the personification of official power-watches over the city and in Luther's writing represents both control over citizens and adult supervision over the young protagonist.

Whereas the new capital reminds the reader of the unequal distribution of welfare, Helsinki's city milieu-which is built on the water-undermines the pastoral so often depicted in literature aimed at young readers. Thus, it strengthens the awareness of the role natural processes forces play in shaping social order. According to David Whitley, urbanized YA literature has, since the 1960s, detached teenagers from nature and the material world. ${ }^{24}$ However, YA literature depicting climate change and other ecological problems attaches the development of young characters to nature again; the story of the protagonist's growth is connected to an awareness of losing control over nature and searching for alternative ecological values. ${ }^{25}$ De hemlösas stad thus outlines the central theme running through all eco-dystopias, namely the Anthropocene and the way modern ecological issues are all-encompassing. There are no more natural habitats unaffected by humans.

Another depiction of the extensive change in the Nordic scenery and the breaking down of state borders is Emmi Itäranta's novel Memory of Water, one of the most well-known dystopias in modern Finnish literature. Like De hemlösas stad, Memory of Water portrays a young girl whose personal growth intertwines with the depiction of a world ruined by climate change, melted ice caps, and the disappearance of the old world. The story, which is set in a distant future, shows us how the Arctic region has turned into a hot button issue of world politics through climate change: the melting of polar ice has opened up new sea routes and revealed oil resources, while at the same time global energy consumption has increased. Thus, the Arctic has become a significant setting of dystopian literature, a stage for natural disaster and war.

It was an account of ruin and devastation, of oceans reaching towards the centres of the continents, swallowing land and fresh water. Millions fleeing their homes, wars fought over fuel resources revealed under the melting ice, until the veins of the earth ran dry. People wounding their world until they lost it. ${ }^{26}$ 
In Memory of Water, a flood has swept across the world. Power is held by the Scandinavian Union, and the original shorelines of the Nordic region were altered long ago. ${ }^{27}$ The story is set in an anonymous, snowless, Arctic area in northern Finland. Like in De hemlösas stad, Western and Eastern cultures have come closer together as climate migration has changed the social structures of Finnish society: this cultural assimilation can be seen, for example, in the name of a village in Lapland called the New Qian (“a precious area”), referring to a Chinese province in which the change in seasons is only minor.

In Memory of Water, the totalitarian and army-led society is based on the regulation of drinking water. Concerns over water rights can be traced back to the debate in the early 2000s about exhausting oil reserves and future wars being fought over water supplies. Vandana Shiva's widely discussed non-fiction book, Water Wars: Privatization, Pollution, and Profit (2002), deals with water as an active form of power and oppression, even as a form of legal terrorism. Shiva was a forerunner in tying the question of water rights to the increased floods and drought resulting from climate change. In Memory of Water, the central question of Shiva's writing remains pivotal: how can one justify the ownership or regulation of a fundamental human necessity like water?

More than Luther's YA fiction, Memory of Water resembles a classic dystopia where the protagonist questions the structures of a totalitarian society and (atypically for YA literature) ultimately perishes. According to Carrie Hintz and Elaine Ostry, the traumatic social and personal awakening of the protagonist is a part of YA literature: the adolescent recognizes the weaknesses and failures of his/her society and rebels. ${ }^{28}$ In an eco-dystopia aimed at young readers, the traditional child savior is thereby transformed into an environmental savior, but both Luther and Itäranta provide only an open-ended story, which is a typical trait of critical dystopias that combine elements of utopia and dystopia. ${ }^{29}$ In Memory of Water, the rebellion is resumed by the protagonist's friend after her death, and in De hemlösas stad, a new tsunami hits Helsinki, emphasizing constant change as an inescapable part of life and marking childhood as a utopian state. The open-ended eco-dystopias leave the reader to ponder the effects his/her choices have in reality. At the same time, these novels exemplify how the portrayals of childhood are less idealized in Finnish YA literature than they were before.

Girlhood and fairy tale intertexts in Finnish YA dystopias 
In contemporary YA dystopias, the child savior who aims to save herself and her fellow human beings or even the whole of humankind is often a girl or a young woman. The girl protagonists of YA dystopias try to understand their place in the world and make their societies more egalitarian, progressive, and free. Sara K. Day, Miranda A. Green-Barteet, and Amy M. Montz have compared the female protagonists of YA dystopias to the girl protagonists of twentiethcentury adolescent literature, since both fight against limitations related to their gender and age. $^{30}$ Riikka Lauttamus and Sanna Karkulehto have noticed a similar continuation of girl protagonists in contemporary Finnish fantasy literature. They see the strong and independent girl character of Finnish YA fantasy fiction acting like the active girl characters of Nordic adolescent literature dating from the early twentieth century onward. ${ }^{31}$ Most of novels we discuss in this article have a young girl as a protagonist, and this seems to be a global tendency in dystopian fiction, a genre where feminist themes have become frequent.

Since Margaret Atwood's The Handmaid's Tale (1985), female protagonists have appeared increasingly frequently in dystopian fiction. Atwood's novel was groundbreaking with its feminist themes and its female protagonist, whose resistance lies in her narration. In the canonized and classical dystopias preceding Atwood's novel, the main characters were male. ${ }^{32}$ With its references to "Little Red Riding Hood" and "Bluebeard," The Handmaid's Tale is also a forerunner in the usage of fairy tale intertextuality. Numerous YA dystopias with female protagonists feature fairy tale intertexts. Anna Sheenan's YA dystopia A Long, Long Sleep (2011) combines elements of “Sleeping Beauty” with a dystopian plot. Marissa Meyer’s Cinder (2012) uses plot elements of "Cinderella" in a dystopian and futuristic setting. In Finnish dystopian YA fiction, fairy tale elements are to be found in the dystopian novels Pelko ihmisessä (2013 [Fear in Human], untranslated) and Ihmisen puolella (2013 [On the Side of Humans], untranslated) by Siri Kolu, as well as in the feminist dystopian fantasies Naondel (2013) by Maria Turtschaninoff and Kolmas sisar (2018 [The Third Sister], untranslated) by Magdalena Hai. Salla Simukka's YA dystopias Jäljellä and Toisaalla refer to fairy tales by Hans Christian Andersen and the Brothers Grimm. All of these novels have young female protagonists.

Gender and sexuality are major themes in contemporary YA dystopias and post-apocalypses, and they often include a heterosexual romance plot. ${ }^{33}$ Balaka Basu, Katherine R. Broad, and Carrie Hintz argue that YA dystopias are often as conservative in their depiction of sexuality as romance novels are-queer relationships are relatively rare in Anglo-American YA 
dystopias. ${ }^{34}$ In Finnish YA literature, however, this is not the case. For example, in Enoranta's Nokkosvallankumous, the rebellious male protagonists are in a romantic relationship. In the post-apocalyptic society depicted in this novel, homosexuality is not marginalized, instead it is considered as normal as heterosexuality. In Simukka’s novels Jäljellä and Toisaalla, young characters have both heterosexual and homosexual experiences, and heterosexuality is not a norm among the youths. Magdalena Hai's dystopian YA novel Kolmas sisar tells a story of two female witches who have sex with other females. Same-sex relationships are also depicted in Turtschaninoff's Naondel and Luther's De hemlösas stad.

YA dystopias became popular in Anglo-American literature a few years before this subgenre of dystopian fiction established itself in Finnish literature. Suzanne Collin's The Hunger Games trilogy has a female protagonist, Katniss Everdeen. In Veronica Roth’s Divergent (2011), people are divided into classes according to their qualities. The protagonist of Divergent, Beatrice, belongs to the divergents, a class without any clear definitions. Simukka's dystopian novels Jäljellä and Toisaalla share this theme of classification. Emmi Aalto, the 15-year-old protagonist of Simukka's novels, is labelled a "Potential” in a system that categorizes young people according to their value to society. Potentials are one of the lowest castes among the youths. To be a Potential is to be nothing in the classification system and in the eyes of one's fellow students. ${ }^{35}$

Introverted Emmi loves to read fairy tales, and references to tales by the Brothers Grimm and H. C. Andersen are embedded in the novels. Emmi herself has traits of Andersen's fairy tale “The Little Mermaid” (1837), as her surname, Aalto, means "wave” in Finnish, and she is fifteen years old. Andersen's little mermaid, living beneath the waves of the ocean, has the opportunity to enter the world of humans upon turning fifteen. Emmi Aalto is taken into a virtual game called “The Empty World” at the same age. In this virtual game, Emmi must learn to survive in a world without adults. She does know that she is the subject of a test, and she is taken into the game without her permission. In the game, Emmi needs to be resourceful in order to save herself and the other adolescents that find themselves in an empty city. Both Emmi and the little mermaid are liminal figures who do not belong to any group: the mermaid wants to change form and leave her underwater home, but she cannot live on dry land. As a Potential, Emmi does not have a significant group, but she turns her liminal position into a strength by being able to make her own independent decisions. ${ }^{36}$ 
Although many heroines in classical fairy tales are passive or victims of threats, the way in which YA dystopias use fairy tale references emphasizes the agency of young women. Many contemporary YA dystopias use fairy tale elements in their portrayal of the liminality between childhood and adulthood and the resistance of young people. By using fairy tale intertexts, these novels also discuss questions of gender and sexuality. Fairy tale heroines and dystopian young protagonists share not only the aim for a better life but also the same age-in fairy tales and YA dystopias, many protagonists are turning fifteen and are in the middle of puberty. Both fairy tale protagonists and the main characters of YA dystopias struggle in society, and especially in YA dystopias, this struggle is combined with a rebellion against authorities, parents, and institutions.

Emmi Aalto believes that her family is ignorant of her problems, and she feels that she has been left alone. She decides to run away, thinking that maybe someone will notice her absence, only to realize that she is one of only a few survivors left in her hometown of Tampere. Only a small number of young people remain in the depopulated city, which means that they have the opportunity to set their own rules. The novel uses post-apocalyptic scenarios and plot details as well as the child rule motif in its depiction of the empty city where young people must survive by themselves. For a while, however, the post-apocalyptic city is a haven of freedom for those who have suffered from bullying. The city is both a utopia and a dystopia for the young people, who have free access to the candy stores and no need to follow the rules set by adults.

Emmi travels with the other young survivors to Helsinki only to find another empty city. Along with two other young citizens, Atro and Onerva, Emmi enters Parliament House in order to find information about the disappearance of humans. This act symbolizes changes in power relations: the adults no longer control the behavior of the young. The empty parliament, with its unfinished memos and legislative papers, also symbolizes the collapse of democracy and political stability. On the island fortress of Suomenlinna [the Castle of Finland], they find a community of young people who have built a democratic and sustainable society with strict rules. This society, which is ruled by adolescents, brings forth a utopian hope for a new order in a world without adults.

Finally, the empty post-apocalyptic world is revealed to be a virtual reality simulation used by adults to control the adolescents. Therefore, the independent agency that the adolescents have 
achieved is only a part of the adults' attempt to control the young. The fairy tale references reveal that the virtual game is nothing but a commercial swindle. A reference to Andersen's story “The Emperor’s New Clothes” (1837)_ “But he doesn’t have anything on!”37—aims at telling both Emmi Aalto and the reader that the virtual world is nothing but an illusion that tricks adolescents. In Simukka's novel, Emmi Aalto is the equivalent of the child who declares the emperor is naked in Andersen's tale. ${ }^{38}$

Simukka quotes the Grimm version of "Hansel and Gretel” (1857) in her novel to symbolize the loneliness the young characters feel. ${ }^{39}$ They feel abandoned by their families and left alone in a world that has become scary and unpredictable. Emmi reads this story in her book of tales and wonders: "The parents really planned to leave their children to die in the woods so that they would have enough food for themselves. What kind of parents would do something like that? Abandon their children to the mercy of beasts and starvation?" 40 The reference to "Hansel and Gretel” opens a theme of survival and children's resourcefulness. Only after being abandoned can Hansel and Gretel become resourceful agents of their own lives. "Hansel and Gretel” is one of the most famous fairy tales with an active girl figure; Gretel plans the siblings’ escape from the house of the wicked witch.

Reading the "Hansel and Gretel” references, Emmi understands that the empty world with its unguarded candy stores is like a gingerbread house—one full of traps—-that she does not know how to escape. The world she lives in has turned into an illusion that reminds of the alluring edible house of the witch. Although Gretel is resourceful, she needs Hansel's help to survive in the forest. In a similar way, Emmi needs another human being who can save her from the world gone weird. This savior is Samuel, a young game nerd who sends her coded fairy tale references that work as clues in the virtual reality in which Emmi is trapped.

Emmi notices a reference to "The Little Mermaid" when she is trapped in a boat with another test subject, Atro. In the fairy tale, the mermaid falls in love with a human prince. She wants to leave her underwater world and assume a human form to be with her love. However, the prince marries another girl, and little mermaid is fated to die if she does not kill the prince with a knife given to her by her sisters. Samuel takes on the role of the sisters when he wants Emmi to stab Atro to make the company cancel the game and rescue Emmi from the agonizing virtual reality. Samuel codes a reference to the Andersen story for Emmi to see: 
We have given our hair to the sea witch, so that she would help you and you would not have to die this night. Here is a knife that the witch has given us. Look how sharp it is! Before the sun rises, you must plunge it into the heart of the prince; when his warm blood sprays on your feet, they will turn into a fishtail and you will be a mermaid again. $^{41}$

The game is interrupted before Emmi stabs Atro to death. Emmi does not follow the example of the little mermaid, who loses her voice after falling in love with the prince. Instead, she gains her own voice in her new community of young people; she has the courage to express her opinions aloud. She manages to oppose Atro, who had played the role of a prince in Emmi's eyes but turned out to be false. Atro knows that he is a subject in a virtual game and tries to benefit from living in a virtual world with young women. In the novel Toisaalla, Emmi returns to her childhood home and family, unlike Andersen's little mermaid, who leaves her underwater home for good and transforms into sea foam when she is left alone without the prince's love. On the contrary, Emmi falls happily in love with Samuel, and she writes a manifesto against commercial game therapy and the classification system that sorts young people according to their talents. ${ }^{42}$ This manifesto is the means by which Emmi regains her own voice and aims at saving other adolescents from the oppressive system.

The dystopia and the fairy tale are both didactic genres that often aim at warning their readers. Dystopias warn about possible threats in the future, while fairy tales have a tendency of highlighting the dangers of immorality, disobedience, or foolish behavior. The Handmaid's Tale combines the warning elements of both genres by referring, quite ironically, to cautionary fairy tales that warn women about the dangers of disobedience. The fairy tale references in YA dystopias may have a cautionary function for the protagonist. In Simukka's novel, the references to fairy tales instruct the protagonist on how to behave in the changed environment. Emmi must behave like a resourceful Gretel who masterminds her survival in the oppressive virtual game.

\section{Conclusion}

Contemporary Finnish YA dystopias employ the generic features of the international dystopian tradition, such as active female characters and a post-apocalyptic world. Above, we have shown 
that contemporary Finnish dystopias also have distinctive national features. These novels are set in Finland or in milieus that resemble Nordic societies. Finnish YA dystopias deconstruct Finnish values and the ideals of equality and democracy. Compared to earlier traditions, contemporary Finnish YA literature imagines worlds that are gloomier than ever. The fears and threats presented in YA literature have shifted from the local and individual to the global. This is in accord with the results of the 2016 Youth Barometer of Finland. According to this survey, only 55 percent of youths held an optimistic view of the future of Finland. Even fewer-just 25 percent-held an optimistic view of the world's future. ${ }^{43}$

YA dystopias reflect collective fears and worries, especially those concerning environmental risks and social inequality. On the other hand, as a popular genre, the YA dystopia can also produce pessimistic and frightening visions of the future. In general, contemporary Finnish YA dystopias seem to be more hopeful than Finnish dystopias aimed at adult audiences. Although the young reader is challenged to learn about the harsh reality of social ills and to evaluate the possible future disasters to which our actions or inactions may lead, young characters hardly ever face hopeless situations. The young protagonist is treated as a representative of the adolescent reader and is therefore seldom fully destroyed.

In our material, most of the young protagonists are variations of the child savior figure, which is connected to the child rule motif commonly found in children's and YA fiction. The child savior in dystopian fiction aims at surviving in the changed environment and saving her or his fellows. In eco-dystopias, the child savior is transformed into an environmental savior. Young characters present alternative values that differ from the destructive values of the adults. They are a promise of a better future. Young protagonists of contemporary Finnish dystopian fiction are typically agents of change in a post-apocalyptic or totalitarian environment. They rebel against the existing regime and try to find solutions to make their surroundings viable by repairing the damage caused by previous generations. Thus, the responsibility for the future of the world is placed on their shoulders.

Notes

1. Isomaa \& Lahtinen, "Kotimaisen nykydystopian monet muodot.” 
2. As a genre, the contemporary Western YA dystopia has already developed some strong generic features that are carefully analyzed in works like Utopian and Dystopian Writing for Children and Young Adults (2003), Contemporary Dystopian Fiction for Young Adults (2013), Environmental Crisis in Young Adult Fiction: A Poetics of Earth (2013), and Female Rebellion in Young Adult Dystopian Fiction (2014).

3. See Hillel, “The Child as Redeemer.”

4. Sambell, Carnivalizing the Future, 252.

5. Hintz \& Ostry, "Introduction,” 5.

6. Ibid., 6.

7. Sambell, Carnivalizing the Future, 252.

8. Skelton, “Taking young people as political actors seriously,” 145.

9. Ibid., 145-146.

10. Enoranta, Nokkosvallankumous, 142.

11. Ibid., 84.

12. This is the plot line, for example, in The Chronicles of Narnia. Kelen \& Sundmark, "Where Children Rule: An Introduction,” 6-7.

13. Ibid., 4-8.

14. Trites, Disturbing, 33.

15. Sundmark 2017a, “The Child Robinsonade,” 96-97.

16. Ibid.

17. Sundmark 2017b, “(Child) Reign of Terror: Dangerous Child Regimes.”

18. See Hennig, Jonasson, \& Degerman, “Introduction,” 1-5.

19. See Lahtinen, “Ilmastonmuutos lintukodossa,” 98-102.

20. Lafuente, “Nationhood, Struggle, and Identity,” 33-35.

21. Bradford \& Baccolini, “Journeying Subjects,” 50.

22. Luther, De hemlösas stad, 11.

23. Bradford \& Baccolini, “Journeying Subjects,” 49.

24. Whitley, “Adolescence and the natural world,” 17.

25. Ibid., 19-21.

26. Itäranta, Memory of Water, 253.

27. Ibid., 68-69.

28. Hintz \& Ostry, “Introduction,” 9.

29. Baccolini \& Moylan, "Introduction: Dystopia and Histories,” 7.

30. Day, Green-Barteet, \& Montz, “Introduction,” 3. 
31. Lauttamus \& Karkulehto, "Heteronormeja vastustavan tyttöyden kompensaatiot,” 25.

32. Samola, Siniparran bordelli, 244.

33. Basu et al., "Introduction,” 8.

34. Ibid., 8.

35. Simukka, Jäljellä, 9.

36. Laakso, "Nuorten lokerointi,” 210.

37. Day, “Docile Bodies, Dangerous Bodies,” 7.

38. Laakso, “Nuorten lokerointi,” 211.

39. Simukka, Jäljellä, 115.

40. Ibid., 15.

41. Simukka, Jäljellä, 216. Translation from Andersen, The Complete Fairy Tales and Stories, 75.

42. Simukka, Toisaalla, 216.

43. Katse tulevaisuuteen, 168-169.

Bibliography

Andersen, Hans Christian. “The Little Mermaid”, in The Complete Fairy Tales and Stories. Translated by Erik Christian Haugaard. New York: Anchor Books, 1983.

Baccolini, Raffaella, and Tom Moylan. "Introduction. Dystopia and Histories”, in Dark Horizons. Science Fiction and the Dystopian Imagination. Edited by Raffaella Baccolini and Tom Moylan. New York and London: Routledge. 1-12, 2003.

Basu, Balaka, Katherine R. Broad, and Carrie Hintz. “Introduction”. Contemporary Dystopian Fiction for Young Adults. Brave New Teenagers. Edited by Balaka Basu, Katherine R. Broad, and Carrie Hintz. New York and London: Routledge. 1-15, 2014. 
Bradford, Clare and Raffaella Baccolini: “Journeying Subjects: Spatiality and Identity in Children's Texts”, in Contemporary Children's Literature and Film. Engaging with Theory, edited by Kerry Mallan and Clare Bradford. Palgrave McMillan, Houndmills, 2011.

Day, Sara K., Miranda A. Green-Barteet, and Amy L. Montz. ”Introduction: From ”New Woman” to "Future Girl”: The Roots and the Rise of the Female Protagonist in Contemporary Young Adult Dystopias” in Female Rebellion in Young Adult Dystopian Fiction. Edited by Sara K. Day, Miranda A. Green-Barteet, and Amy L. Montz. 1-14, 2016 [2014].

Day, Sara K. "Docile Bodies, Dangerous Bodies: Sexual Awakening and Social Resistance in Young Adult Dystopian Novels", in Female Rebellion in Young Adult Dystopian Fiction, edited by Sara K. Day, Miranda A. Green-Barteet, and Amy M. Montz. London and New York: Routledge. 75-92, 2016.

Enoranta, Siiri. Nokkosvallankumous [Nettle Revolution]. Helsinki: WSOY, 2013.

Halliwell, John F., Richard Layard, and Jeffrey D. Sachs. World Happiness Report 2018. New York: Sustainable Development Solutions Network, 2018.

Hennig, Reinhard; Jonassen, Anna-Karina and Degerman, Peter. "Introduction. Nordic Narratives of Nature and the Environment”, in Nordic Narratives of Nature and the Environment, edited by Reihard Hennig, Anna-Karin Jonassen and Peter Degerman. New York: Lexington Books. 1-18, 2018.

Hillel, Margot. “'A Little Child Shall Lead Them': The Child as Redeemer”, in Children's Literature and the Fin de Siècle, edited by Roderick McGillis. Westport: Praeger. 57-69, 2003.

Hintz, Carrie and Elaine Ostry. "Introduction”, in Utopian and Dystopian Writing for Children and Young Adults, edited by Carrie Hintz and Elaine Ostry. New York \& London: Routledge. 1-22, 2003.

Isomaa, Saija and Lahtinen, Toni. “Kotimaisen nykydystopian monet muodot”, in Pakkovaltiosta ekodystopiaan. Kotimainen nykydystopia, edited by Saija Isomaa and Toni Lahtinen. Joutsen / Svanen Special Studies 2. 7-16, 2017. 
Itäranta, Emmi. Memory of Water. New York: Harper Voyager, 2012/2014.

Kelen, Kit \& Björn Sundmark. "Where Children Rule: An Introduction”, in Child Autonomy and Child Governance in Children's Literature. Where Children Rule, edited by Christopher Kelen and Björn Sundmark. New York \& London: Routledge. 1-15, 2017.

Laakso, Maria. "Nuorten lokerointi ja kehittyminen Salla Simukan nuortendystopiaromaaneissa Jäljellä ja Toisaalla”, in Sananjalka 60/2018. Turku: Suomen kielen seura. 204-215, 2018.

Lafuente, Elia Michelle. "Nationhood, Struggle, and Identity”, in Contemporary Adolescent Literature and Culture. The Emergent Adult, edited by Mary Hilton and Maria Nikolajeva. Surrey: Ashgate, 2012.

Lahtinen, Toni. "Ilmastonmuutos lintukodossa", in Suomen nykykirjallisuus 2. Kirjallinen elämä ja yhteiskunta, edited by Mika Hallila et al. Helsinki. Suomalaisen Kirjallisuuden Seura. 95-106, 2013.

Lauer, Emily. “Coming of Age in Dystopia”, in Contemporary Dystopian Fiction for Young Adults. Brave New Teenagers, edited by Balaka Basu, Katherine R. Broad, and Carrie Hintz. New York: Routledge. 35-50, 2013.

Lauttamus, Riikka and Sanna Karkulehto. "Heteronormeja vastustavan tyttöyden kompensaatiot. Siiri Enorannan Surunhauras, lasinterävä ja Maria Turtschaninoffin Anaché: Myter från akkade -nuortenfantasiaromaaneissa”, in Sukupuolentutkimus-Genusforskning 30(2017): 3, s. 25-38.

Luther, Annika. Kodittomien kaupunki [The City of the Homeless]. Finnish translation Asko Sahlberg. Helsinki: Teos \& Söderström, 2011.

Messner, J. J., ed. Fragile States Index. Washington, D. C.: Fund for Peace, 2018. 
Myllyniemi, Sami, ed. Katse tulevaisuudessa. Nuorisobarometri 2016. https://tietoanuorista.fi/wp-content/uploads/2017/03/Nuorisobarometri_2016_WEB.pdf, 2017.

Sambell, Kay. "Carnivalizing the Future: A New Approach to Theorizing Childhood and Adulthood in Science Fiction for Young Readers”, in The Lion and the Unicorn. 28: 2. pp. 247-267, 2004.

Samola, Hanna. Siniparran bordelli. Dystopian ja sadun lajiyhdistelmät romaaneissa Berenikes hår, Auringon ydin ja Huorasatu. Tampere: Tampere University Press, 2016.

Simukka, Salla. Jäljellä [Still Here]. Helsinki: Tammi, 2012.

Simukka, Salla. Toisaalla [Elsewhere]. Helsinki: Tammi, 2012.

Skelton, Tracey. "Taking young people as political actors seriously: Opening the borders of political geography”, in Area. 42 (2). 145-151, 2010.

Strandgaard Jensen, Helle. From Superman to Social Realism. Children's Media and Scandinavian Childhood. Amsterdam \& Philadelphia: John Benjamins Publishing Company, 2017.

Sundmark, Björn. "The Child Robinsonade”, in Child Autonomy and Child Governance in Children's Literature. Where Children Rule, edited by Christopher Kelen and Björn Sundmark. New York \& London: Routledge. 84-95, 2017a.

Sundmark, Björn. “(Child)Reign of Terror: Dangerous Child Regimes”, in Child Autonomy and Child Governance in Children's Literature. Where Children Rule, edited by Christopher Kelen and Björn Sundmark. New York \& London: Routledge. 96-106, 2017b.

Trites, Roberta Seelinger. Disturbing the Universe. Power and Repression in Adolescent Literature. Iowa: University of Iowa Press, 2000. 
Whitley, David. “Adolescence and the Natural World in Young Adult Fiction”, in Contemporary Adolescent Literature and Culture. The Emergent Adult, edited by Mary Hilton and Maria Nikolajeva. Surrey: Ashgate, 2012. 